\title{
COMPARATION OF RUBBER MILLING PROCESS TO PRODUCE NATURAL RUBBER COUMPOUNDS USING MODIFIED AND UNMODIFIED LOCAL CLAY FILLER
}

\author{
Abu Hasan ${ }^{1}$, Martha Aznury$^{1}$, Indah Purnamasari', Muhammad Zaman', \\ Robert Junaidi ${ }^{1}$ and Rahmaniar ${ }^{2}$ \\ ${ }^{1} J u r u s a n$ Teknik Kimia - Politeknik Negeri Sriwijaya \\ Jl. Srijaya Negara Bukit Besar, Palembang 30139 \\ ${ }^{2}$ Baristand Industri Palembang \\ Jl. Perindustrian II no. 12 KM 9 Sukarami, Palembang 30152 \\ E-mail: abu_hasan@polsri.ac.id
}

Received: 15 September 2019 Revised: 20 December 2019 Accepted: 27 December 2019

\begin{abstract}
COMPARISON OF RUBBER MILLING PROCESS TO PRODUCE NATURAL RUBBER COMPOUNDS USING MODIFIED AND UNMODIFIED LOCAL CLAY FILLER. Many researchers have studied the effect of modified clay as filler on rubber compounds for both natural rubber and synthetic rubber. Various chemicals are used as clay modifiers. In the rubber milling process, modified clay is directly used as filler after pretreatment with clay modifier. However, clay modifiers can also be milled together with original clay during the rubber mastication and milling process. Thus both of these methods certainly produce different physical properties, so the comparison of the two rubber milling processes is the focus of this research. The analysis of the curing characteristics and physical properties of vulcanized natural rubber was carried out with a rheometer and physical properties test units. Thermal analysis was carried out using TG/DTA and dispersion of filler on the rubber compound was analyzed by SEM. The results of the curing characteristic of the rubber compound and the physical properties of vulcanization showed that there was an effect due to the comparison of the rubber milling process. Modified clay using JH-S69 is better than JH-S69 milled with original clay and vice versa occurs in PEG 4000 which is used as clay modifier. PEG 4000 which is milled together with original clay produces curing characteristic and physical properties of vulcanization better than pretreatment of clay to be modified clay. This analysis is in line with the analysis using SEM.
\end{abstract}

Keywords: Rubber, Composites, Curing, Clay, Milling process

\begin{abstract}
ABSTRAK
PERBANDINGAN PROSES PENGGILINGAN KARET UNTUK MENGHASILKAN KOMPON KARET ALAM MENGGUNAKAN BAHAN PENGISI TANAH LIAT LOKAL YANG TERMODIFIKASI DAN TAK TERMODIFIKASI. Banyak peneliti telah mempelajari pengaruh tanah liat yang dimodifikasi sebagai pengisi pada kompon karet alam dan karet sintetis. Berbagai bahan kimia digunakan sebagai pemodifikasi tanah liat. Dalam proses penggilingan karet, tanah liat yang dimodifikasi langsung digunakan sebagai pengisi setelah pretreatment dengan pemodifikasi. Namun, pemodifikasi tanah liat juga dapat digiling bersamaan dengan tanah liat selama proses mastikasi dan penggilingan karet. Dengan demikian kedua metode ini tentu saja menghasilkan sifat fisik yang berbeda, sehingga perbandingan dari dua proses penggilingan karet adalah fokus dari penelitian ini. Analisis sifat curing dan sifat fisik karet alam tervulkanisasi dilakukan dengan alat uji reologi dan sifat fisik. Analisis termal dilakukan dengan menggunakan TG/DTA dan dispersi pengisi pada senyawa karet dianalisis dengan SEM. Hasil sifat curing kompon karet dan sifat fisik tervulkanisasi menunjukkan bahwa ada pengaruh karena perbandingan proses penggilingan karet ini. Tanah liat yang dimodifikasi menggunakan JH-S69 lebih baik daripada JH-S69 yang digiling dengan tanah liat dan sebaliknya terjadi pada PEG 4000 yang digunakan sebagai pemodifikasi tanah liat. PEG 4000 yang digiling bersama dengan tanah liat menghasilkan sifat curing dan sifat fisik vulkanisat yang lebih baik daripada perlakuan awal tanah liat yang akan dimodifikasi. Analisis ini sejalan dengan analisis menggunakan SEM.
\end{abstract}

Kata kunci: Karet, Komposit, Curing, Tanah liat, Penggilingan 


\section{INTRODUCTION}

In the design of rubber compounds, the presence of fillers is needed and a very important role [1-3]. The filler in the rubber compound can function as an amplifier, semi-reinforcement, and not as a reinforcement or inert. Silica is a filler for rubber that has semi reinforcing properties. There are also those who report that the Sugarcane bagasse fiber can function as a semireinforcement in natural rubber [4]. Local clay is also material that contains quite a lot of silica $50.83-75.29 \%$ [5], which can automatically be semi-reinforced. Research on the use of clay as a filler against rubber compounds has been carried out [6-18] including modification of clay [19-31].

From a number of these authors below, not a single writer has conducted a study with the difference in the process of rubber grinding with modified clay as a filler. In 2010, Liu at. al. [7] uses polyethylene glycol (PEG) as an ingredient to modify clay. PEG and clay are dissolved in demineralized water and stirred for 4 days, then centrifugation is carried out and drying and refining are required. Modified clay is ready for use. Likewise with Zhang et. al. [8] where clay is processed in such a way using bis (triethoxysilylpropyl) tetrasulfide ( $\mathrm{Si} 69$ ) so that modified clay is obtained. Clay is reacted with $\mathrm{Si}$ 69 in water. Clay is then dispersed in water with a content of $20 \%$ and $0.7 \% \mathrm{Si} 69$ for 1 hour at $80^{\circ} \mathrm{C}$. Modified clay is filtered and dried at $110^{\circ} \mathrm{C}$, then smoothed and ready to be used as a filler. Both Liu [7] and Zhang [8] used modified clay for rubber fillers.

The important thing to note is that the filler can function optimally as a booster. Here the process of rubber mastication and milling needs to be optimized. This process can increase the bound rubber where the bound rubber is an indicator of reinforcement in vulcanizing natural rubber [32-33].

In the manufacturing process, carbon black which is produced from the petroleum fraction, still dominates some of the filler in rubber. The petroleum fraction is burned with an atmosphere of lack of oxygen and one of the combustion products is $\mathrm{CO}_{2}$. The impact of $\mathrm{CO}_{2}$ emissions can cause a decrease in environmental quality.

Based on the description, the difference in the milling process between the modified clay filler and clay modifier mixed with original clay during rubber milling process is the main objective of this study.

\section{EXPERIMENTAL METHOD}

\section{Materials and Mixing}

The rubber used in this study was natural rubber RSS 1 made by PT PN IX Semarang, Indonesia. Local clay originated from the coal mining area of PT Bukit Asam South Sumatra in Indonesia which was selfprocessed and characterized. This clay is consisted of
$\mathrm{SiO}_{2}$ and kaolin. Sulfur Midas SP-325 by Miwon Chemicals Co. 1td. Korea, TMTD Accelerator by Qingdao Ever Century Trading Co., Ltd. China, ZnO Zinkoxyd Aktiv UN 3077 and TMQ Vulkanox HS / LG by LANXESS Deutschland GmbH Germany, stearic acid Aflux 52 by Rhein Chemie Rheinau Mannheim GmbH Germany. Clay modifiers consist of Silane coupling agent JH-S69 produced by Jianghan fine chemical co. ltd. China and PEG 4000 by Lotte Chemical Korea. All these rubber chemicals are untreated and immediately used.

Natural rubber compound preparation was carried out using an open two roll mill Berstoff Germany with a capacity of $1 \mathrm{~kg}$ compound. Compound of I A was a natural rubber compound with pre-treated clay using JH-S69 or modified clay as a filler. While the compound where the JH-S69 is milled together with original clay on the rubber milling process called compound of I B. The process of making modified clay using clay modifier JHS69 was done in the same way as Zhang et. al. [8].

The clay in compound II A was modified using a PEG 4000 modifier. The clay modification process followed the process carried out by Liu et.al. [7]. On the other hand, the treatment of compound II B was different from compound II A. Here the clay was modified using PEG 4000 which was carried out during the grinding process. The clay and PEG 4000 were milled together when the milling process was carried out on an open two roll mill. The following is presented in Table 1 which is a rubber formula design in the implementation of this research.

Table 1. Natural rubber formula for compounding preparation.

\begin{tabular}{llrrrr}
\hline \multirow{2}{*}{ No } & Rubber and rubber chemicals & \multicolumn{4}{c}{ Ingredients [phr] } \\
\cline { 3 - 6 } & & I A & I B & II A & II B \\
\hline 1 & Rubber RSS 1 & 100 & 100 & 100 & 100 \\
2 & Modified clay & 15 & - & 15 & - \\
3 & Unmodified clay & - & 15 & - & 15 \\
4 & JH-S69 & - & 0.55 & - & - \\
5 & PEG 4000 & - & - & - & 0.55
\end{tabular}

\section{Characterization}

The cure properties of vulcanized natural rubber were determined by MDR 2000 (Alfa technology, US) using ASTM D 5289. Flex cracking test used ASTM D430 - 06(2012), and rebound resilience (ISO 4662: 2017, LUPKE). The equipment used for tear strength was tensometer Lloyd 2000 (England) with a tensile speed of $50 \mathrm{~cm} / \mathrm{min}$. Thermal analysis using TGA/ DTA Hitachi STA 7300 (Japan) was done in the heating rate of $10^{\circ} \mathrm{C} /$ min and temperature range of $30-500{ }^{\circ} \mathrm{C}$ under nitrogen atmosphere. SEM analysis using JEOL JSM 6360LA (Austin, US) at $10 \mathrm{kV}$.

\section{RESULT AND DISCUSSION}

From Figure 1, there are differences in the curing characteristics of natural rubber composites. It turns out 
that the difference in the compound manufacturing process can cause the torque differences seen in IA and I B samples. There is a decrease in curing characteristics of natural rubber compounds. the difference in torque in Figure 1 is caused by a vulcanization reaction. This reaction results in an increase in the stiffness of the rubber compound which in turn affects the strength of the rubber. The modified clay first gives a better influence on the rubber compound's properties compared to the modified clay through the compound rubber milling process. The reaction of solids and liquids between the original clay and JH-S69 when milled together in making rubber compounds is no better than the direct reaction between the original clay and JH-S69. The reaction of the original clay with JH-S69 is not affected by the shear strength of the rubber, whereas the original clay and JH-S69 are ground together when making rubber compounds influenced by the shear strength of the rubber.

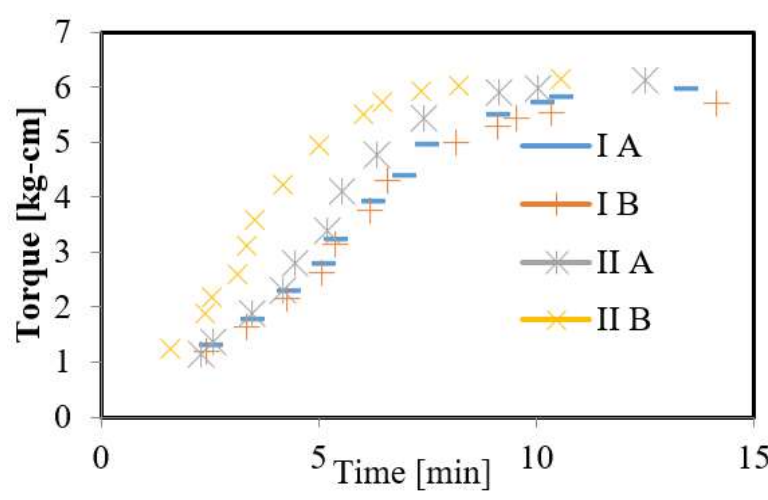

Figure 1. The relationship between torque caused by rubber stiffness and vulcanization time of natural rubber composites.

What happened in sample I A and I B did not occur in sample II A and II B. Here there is an increase in the parameters of curing characteristics. This means that the modification of the clay made during rubber milling gives better rubber compound properties compared to the modified clay. This difference in curing characteristics of samples II A and II B is shown in Table 2 and Figure 1.

Table 2. Curing characteristic of natural rubber composites.

\begin{tabular}{lcccc}
\hline \multirow{2}{*}{ Curing characteristics } & \multicolumn{4}{c}{ Natural rubber composites } \\
\cline { 2 - 5 } & I A & I B & II A & II B \\
\hline $\begin{array}{l}\text { Maximum torque-minimum } \\
\text { torque [kg-cm] }\end{array}$ & 5.53 & 5.00 & 5.57 & 5.82 \\
Maximum torque [kg-cm] & 6.00 & 5.69 & 6.11 & 6.15 \\
Minimum torque [kg-cm] & 0.47 & 0.69 & 0.54 & 0.33 \\
Optimum cure [min;s] & 9.02 & 8.51 & 8.00 & 6.13 \\
Scorch time [min;s] & 4.51 & 5.09 & 4.31 & 3.01 \\
\hline
\end{tabular}

The reaction between original clay and PEG 4000 is a solid-solid reaction. This solid reaction occurs during the rubber milling process where the original clay and PEG 4000 are included simultaneously. The curing characteristics are better than the modified clay before the rubber milling process. This solid reaction causes more contact between PEG 4000 and original clay. Shear stress of rubber during milling process greatly helps contact between PEG 4000 and original clay. The contact time between PEG 4000 and original clay causes these particles to become finer so as to form a modified clay. Thus, the clay can function well as a rubber filler. As a result of the differences in the rubber milling process, the vulcanization reaction speed is also influenced as shown in Figure 2. Samples I and II are distinguished from the type of clay modifier.

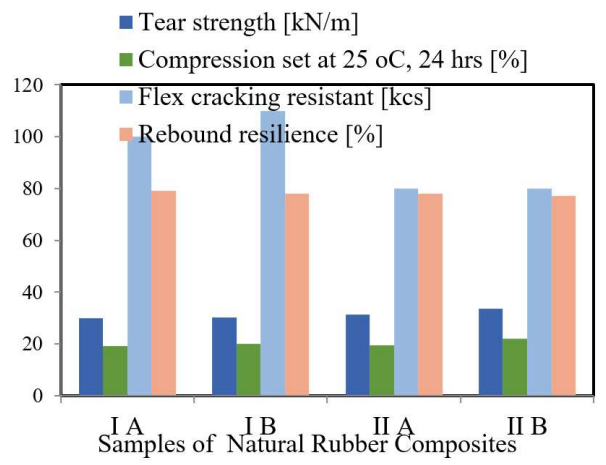

Figure 2. Physical properties of vulcanized natural rubber composites.

The torque shown in Figure 1 shows that there are differences in the speed of the vulcanization reaction between samples of I A, I B, II A, and II B. From Figure 1, the vulcanization reaction velocity of sample I A higher than sample I B also vice versa occurs in sample II A and II B. Samples II B show a higher reaction speed compared to sample II A. The difference in rubber milling process also has an impact on physical properties of vulcanized natural rubber.

From Figure 2 it can be seen that the physical properties of natural rubber vulcanisate decreased from I A sample to I B sample, on the contrary there was an increase in the physical properties of vulcanized natural rubber from sample II A to II B. For example, tear resistance, sample I A had $29.8 \mathrm{kN} / \mathrm{m}$ relatively unchanged to $30.3 \mathrm{kN} / \mathrm{m}$ for sample I B, on the contrary the sample II A tear resistance is $31.3 \mathrm{kN} / \mathrm{m}$ to $33.5 \mathrm{kN} / \mathrm{m}$ for sample II B. Decrease from I A to I B or increase from II A to II B the physical properties of vulcanized rubber are due to the difference in the rubber milling process. The difference in the rubber milling process causes differences in the velocity of the vulcanization reaction so that it affects the physical properties of the vulcanization.

SEM analysis for fillers dispersion for samples I A, I B, II A, and II B can be seen in Figure 3. From SEM observations as shown in Figure 3, sample I A has clearer and coarser particles compared to sample I B at the same magnification, but the particles in sample I B are covered by rubber chemicals on their surface so they cannot function properly as fillers. 


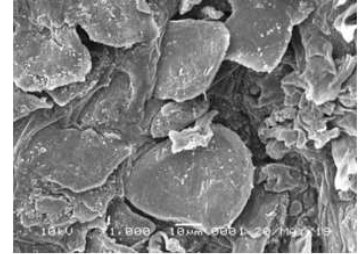

IA

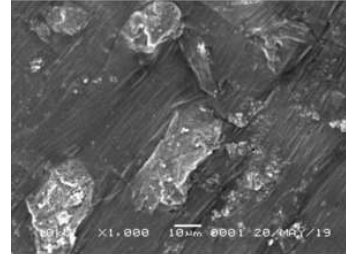

I B

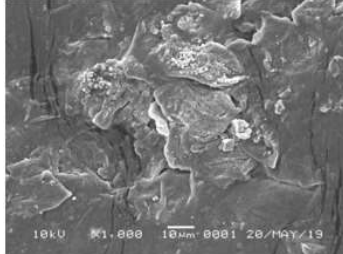

II A

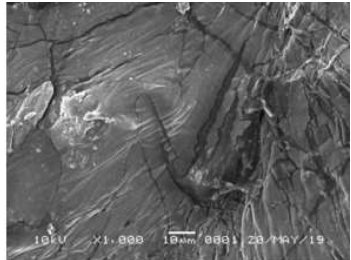

Figure 3. SEM analysis of natural rubber composites: samples I A and II A are samples using modified Clay and samples I B and II B using original clay milled together with clay modifier.

This is caused by limited interaction between $r$ ubber molecules and fillers. therefore the reinforcement of the rubber is low. As a result there is a decrease in the physical properties of vulcanized natural rubber.

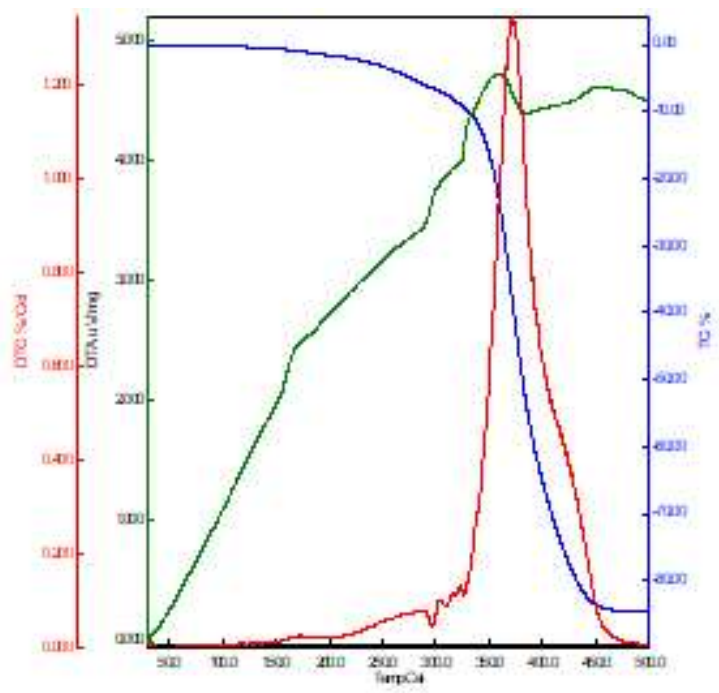

(a)

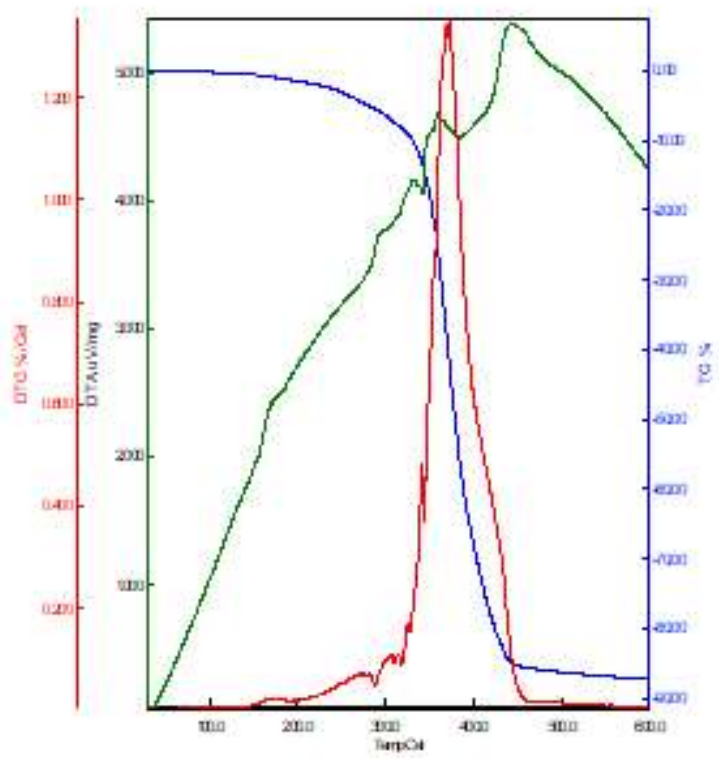

(c)
Observation in SEM analysis for samples II A and II B, sample II B expressed smoother on the surface compared to sample II A. It turns out that the rubber grinding process causes better dispersion of modified

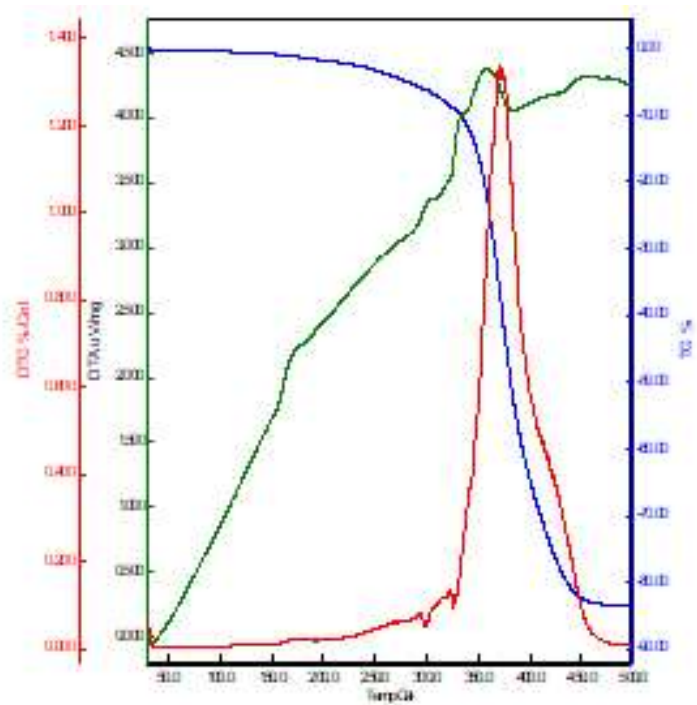

(b)

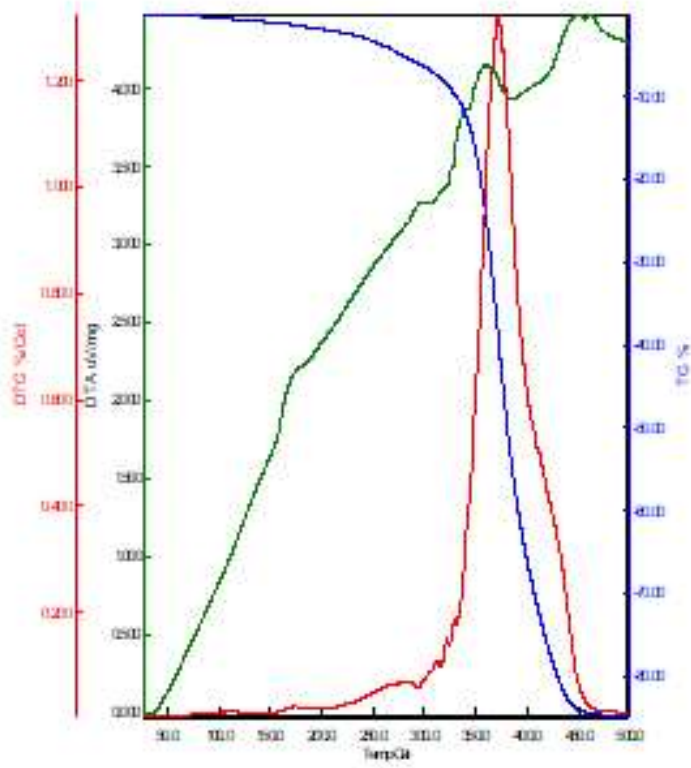

(d)

Figure 4. Thermal analysis of natural rubber composites. (a). sample I A, (b). sampel I B, (c). sample II A, and (d). sampel II B. 
clay. This good filler dispersion causes the physical properties of the rubber vulcanisate of sample II B better than sample II A.

\section{Thermal Properties}

The results of thermal analysis can be seen in Figure 4 (a-d). This picture presents a thermal analysis of natural rubber composites which is distinguished from the rubber milling process. The sample with code $\mathrm{A}$ is a sample with modified clay and code B sample which is milled simultaneously between clay modifier and original clay while code I and II where the sample uses a different clay modifier. Noting Figure 4 (a-d), it turns out that differences in the milling process and differences in the clay modifiers used have not been well observed, therefore Figure 5 is needed to explain the effect of different milling processes and differences in clay modifiers used in rubber compounds.

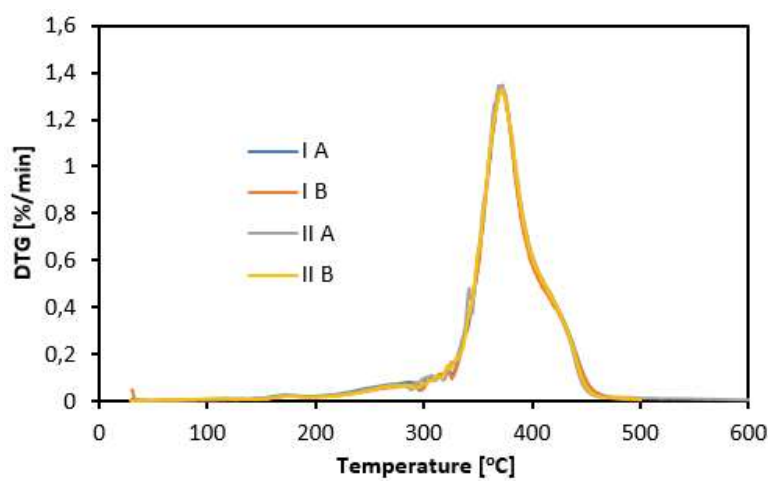

Figure 5. DTG thermal analysis of natural rubber composites, samples I A, I B, II A, and II B.

From Figure 5, it is also not yet known the effect of the different milling processes and differences in clay modifiers on the rubber compound. The difference for each mass loss rate cannot be known for each temperature. The curve in Figure 5 still looks stacked with each other so that Figure 6 is needed to explain the effect of the different milling processes and the difference in clay modifier on the rubber compound.

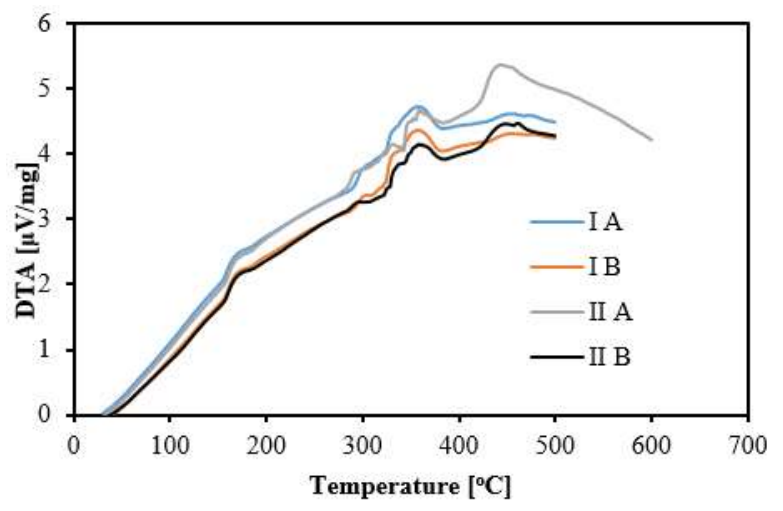

Figure 6. DTA thermal analysis of natural rubber composites of samples I A, I B, II A, and II B.
Figure 6 shows the difference in thermal properties of the four natural rubber composites as the effect of the rubber milling process and the difference in clay modifier used. Sample I A, volume shrinkage is higher for each sample mass compared to sample I B and so is sample II A greater than sample II B.

Figure 7 also helps explain differences in the thermal properties of samples I and II. In this figure, TG information is given for samples I A, I B, II A, and II B. TG differs from each sample around the observation temperature of $375-500{ }^{\circ} \mathrm{C}$. TG for sample I A was $-85 \%$, I B was $-84 \%$, II A was $-87 \%$, and II B was $-85 \%$ at $500{ }^{\circ} \mathrm{C}$. The TG at $50 \%$ volume reduction (TG50) for sample I A was $381^{\circ} \mathrm{C}$, I B $381{ }^{\circ} \mathrm{C}$, II A $379^{\circ} \mathrm{C}$, and II B $381{ }^{\circ} \mathrm{C}$. Here there is almost no difference in TG 50 , but there is a difference of around $2{ }^{\circ} \mathrm{C}$ between samples II A and II B. Of course differences in the rubber milling process affect the TG50 value. Modified clay as filler in sample II B caused interaction between rubber molecules and modified clay filler better than sample II A. In other words, modified clay can function more as a reinforcement on rubber so that this effect can shift TG50.
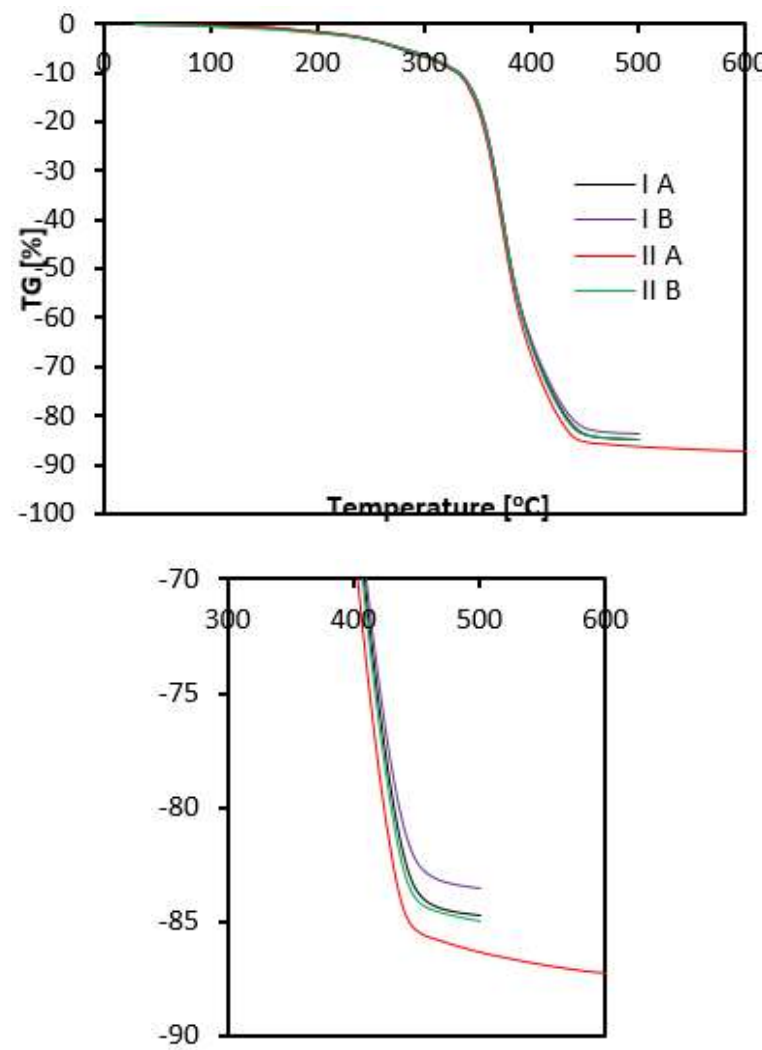

Figure 7. TG thermal analysis of natural rubber composites, samples I A, I B, II A, and II B.

Taking into account the curves in Figures 6 and 7, the IB sample is more stable than the IA sample and sample II B is more stable than sample II A. This also means that the milling process of the clay modifier and the original clay modifier together is better than the pretreatment of clay first. The milling process can lead 
to better clay contact and clay modifiers so as to increase the thermal stability of IB and II B. Dispersed clay produces a barrier that can delay the release of thermal degradation products so that the IB is more stable than IA samples and sample II B is more stable than sample II A

\section{CONCLUSION}

The conclusions obtained from the description in the discussion are rubber milling process affects the physical properties of vulcanized natural rubber. The results of the dispersion analysis of fillers in rubber using SEM support the explanation of the differences in the physical properties of vulcanized natural rubber. The physical properties of sample I A are better than sample I B and sample II B is better than sample II A. The thermal analysis results show that the sample I B is more stable than sample I A as well as sample II B is more stable than sample II A. This also means that milling of unmodified clay and clay modifiers together is better than milling of modified clay.

\section{ACKNOWLEDGMENT}

This work was supported by Directorate General of Strengthening Research and Development, Ministries of Research, Research, and Higher Education, Republic of Indonesia with the scheme of Higher Education Applied Research under contract number 153/SP2H/LT/ DRPM/2019 dated 11 of March 2019.

\section{REFERENCES}

[1] E. H. Andrews, "Reinforcement of Rubber by Fillers," Rubber Chem. Technol., vol. 36, no. 2, pp. 325-336, May 1963.

[2] M. Morton. "Filler," in Rubber Technology, New York: Van Nostrand Reinhold, 1987, pp. 59-104.

[3] D. Jia, L. Liu, X. Wang, B. Guo, and Y. Luo, "Advances in Natural Rubber/Montmorillonite Nanocomposites," in Biodegradable Polymer Blends and Composites from Renewable Resources, New Jersey: John Wiley \& Sons, 2008, pp. 415-433.

[4] F. Paiva et al., "Sugarcane bagasse fiber as semireinforcement filler in natural rubber composite sandals," J. Mater. Cycles Waste Manag., vol. 21, no. 2pp. 326-335, Oct. 2018.

[5] A. Hasan et al., "Potential of Clay in Coal Mining of Tanjung Enim Area as a Filler on Rubber Compound,' J. Phys. Conf. Ser., vol. 1167, p. 12042, 2019.

[6] D. Jia, L. Liu, X. Wang, B. Guo, and Y. Luo, "Advances in Natural Rubber/Montmorillonite Nanocomposites," in Biodegradable Polymer Blends and Composites from Renewable
Resources, New Jersey: John Wiley \& Sons, 2008, pp. 415-433.

[7] Y. Zhang, Q. Liu, Q. Zhang, and Y. Lu, "Gas Barrier Properties of Natural Rubber/kaolin composites prepared by melt blending." Applied Clay Sci., vol. 50, pp. 255-259, 2010.

[8] C.Albano, M. Hernandez, M. N. Ichazo, J. Gonzalez, and W. De Sausa, "Characterization of NBR/ Bentonite Composites: vulcanization kinetics and rheometric and mechanical properties." Polym. Bull, vol. 67, no. 4, pp. 653-667, 2011.

[9] V. C. Panwar and D. K. Sharma, "A review: polystyrene /clay nanocomposites". J. Reinf. Plast Compos, vol. 30, no.5, pp. 446-459, 2011.

[10] H. Ismail and M. Mathialagan, "Curing Characteristics, Morphological, Tensile and Thermal Properties of Bentonite-Filled EthylenePropylene-Diene Monomer (EPDM) Composites." Polym. - Plast. Technol. Eng, vol. 50, pp. 14211428, 2011.

[11] S. Lalikova et al., "Investigation of natural rubber composites with addition of montmorillonite fillers using thermal analysis." J. Therm. Anal. Calorim., vol. 104,pp. 969-973, 2011.

[12] C. Albano et al., "Nitrile Rubber-Bentonite Composites: A Thermal Degradation Study." Polym. Bull., vol. 68, no. 7, pp. 1935-1950, 2012.

[13] H. Goodman and A. Riley. "Clay Mineral Products and Their Use in Rubber Compositions." U.S. Patent 8183316 B2, 2012.

[14] Q. Zhang, Y. Zhang and Y. Wang, "Mechanical and thermal properties of kaolin/Natural rubber nanocomposites prepared by the conventional two-roll mill method." Appl. Mech. Mater., vol. 164, pp. 142-145, 2012.

[15] K. Szustakiewicz, B. Cichy, M. Gazińska, and J. Pigłowski, "Comparative study on flame, thermal, and mechanical properties of HDPE/clay nanocomposites with MPP or APP.” J. Reinf. Plast. Compos., vol. 32, no.14, pp. 1005-1017, 2013.

[16] Y. Zhang, Q. Zhang, Q. Liu, H. Cheng, and R. L. Frost, "Thermal stability of styrene butadiene rubber (SBR) composites filled with kaolinite/silica hybrid filler." J. Therm. Anal. Calorim., vol. 115, pp. 1013-1020, 2014.

[17] J. Ruamcharoen, T. Ratana, and P. Ruamcharoen, "Bentonite as a Reinforcing and Compatibilizing Filler for Natural Rubber and Polystyrene Blends in Latex Stage." Polym. Eng. Sci., vol. 54, no.6, pp 1436-1443, 2014.

[18] A. Ambre, R. Jagtap, and B. Dewangan,"“ ABS Nanocomposites Containing Modified Clay." J. Reinf. Plast. Compos, vol. 28, no.3, pp. 343-352, 2008.

[19] R. Sukumar and A. R. R. Menon, "Organomodified Kaolin as a Reinforcing Filler for Natural Rubber." J. Appl. Polym. Sci., vol. 107, pp. 3476-3483, 2008. 
[20] L. E. Yahaya, K. O. Adebowale, and A. R. R. Menon. "Mechanical Properties of Organomodified Kaolin/ Natural Rubber Vulcanizates. Appl. Clay Sci., vol. 46, pp. 283-288, 2009.

[21] S. B. Jagtap, V. S. Rao, and D. Ratna, "Preparation of flexible epoxy/clay nanocomposites: effect of preparation method, clay modifier and matrix ductility." J. Reinf. Plast. Compos., vol. 32, no.3, pp. 183-196, 2013.

[22] A. Saritha, K. Joseph, S. Thomas, and R. Muraleekrishnan, "The Role of Surfactant Type and Modifier Concentration in Tailoring the Properties of Chlorobutyl Rubber/Organo Clay Nanocomposites.” J. Appl. Polym. Sci. vol. 124, pp. 4590-4597, 2012.

[23] O. J. Ogbebor, F. E. Oikiemen, D. E. Ogbeifun, and U. N. Okwo, "Organomodified Kaolin as Filler for Natural Rubber." Chem. Ind. Chem. Eng., vol. 21, no.4, pp. 477-484, 2015.

[24] O. J. Ogbebor, F. E. Oikiemen, D. E. Ogbeifun, and U. N. Okwo, "Preparation and Properties of Organokaolin Natural Rubber Latex Vulcanizate." Adv. Mater, vol. 4, no.4, pp. 75-79, 2015.

[25] D. Puglia et al., "Influence of Processing Conditions on Morphological, Thermal and Degradative Behavior of Nanocomposites Based on Plasticized Poly (3-hydroxybutyrate) and Organo-Modified Clay." J. Polym. Environ., vol. 24, no.1, pp. 12-22, 2016.

[26] S. H. Sheikh, X. Yin, A. Ansyarifar, and K. Yendall, "The Potential of Kaolin as A Reinforcing Filler for Rubber Composites with New Sulfur Cure Systems.” J. Reinf. Plast. Compos., vol. 36, no.16, pp. 1132-1145, 2017.

[27] R.V. Sreelekshmi, M. Brahmakumar, J.D. Sudha, and A. R. R. Menon., "Studies on Natural Rubber Containing Kaolin Modified with Hexamethylene diamine Derivative of Phosphorylated Cashew Nut
Shell Liquid Prepolymer.” Appl. Clay Sci., vol. 141, pp. 171-179, 2017.

[28] B. Kord, P. Ravanfar, and N. Ayrilmis, "Influence of Organically Modified Nanoclay on Thermal and Combustion Properties of Bagasse Reinforced HDPE Nanocomposites.” J. Polym. Environ., vol. 25, no.4, pp. 1198-1207, 2017.

[29] R.V. Sreelekshmi, J.D. Sudha, and A. R. R. Menon, "Novel Organomodified Kaolin/Silica Hybrid Fillers in Natural Rubber and Its Blend with Polybutadiene Rubber.” Polym. Bull., vol. 74, no.3, pp. 783-801, 2017.

[30] R. Peter, R.V. Sreelekshmi, and A. R. R. Menon, "Cetyltrimethyl Ammonium Bromide Modified Kaolin as A Reinforcing Filler For Natural Rubber." J. Polym. Environ. vol. 26, no.1, pp. 39-47, 2018.

[31] A. Hasan, Rochmadi, H Sulistyo and S Honggokusumo, "Effect of Rubber Mixing Sequence Variation Upon Bound Rubber Formation and Its Physical Properties." Ind. J. Chem., vol. 25, no. 9, pp. 5203-5207, 2013.

[32] A. Hasan, Rochmadi, H. Sulistyo and S. Honggokusumo, "Rubber mixing process and its elationship with bound rubber and crosslink density," in IOP Conf. Series: Mater. Sci. Eng., 2017, vol. 213, p. 12048.

[33] ASTM D5289-17. Standard Test Method for Rubber Property-Vulcanization Using Rotorless Cure Meters.

[34] ASTM D624-00(2012). Standard Test Method for Tear Strength of Conventional Vulcanized Rubber and Thermoplastic Elastomers.

[35] ASTM D395-18. Standard Test Methods for Rubber Property-Compression Set.

[36] ASTM D430 - 06(2012). Standard Test Methods for Rubber Deterioration-Dynamic Fatigue.

[37] ISO 4662:2017. Rubber, vulcanized or thermoplastic-Determination of rebound resilience. 